\title{
Evaluation of the infectivity and the persistence of Trichinella patagoniensis in muscle tissue of decomposing guinea pig (Cavia porcellus)
}

\author{
F. Fariña ${ }^{1,2} \cdot$ M. Pasqualetti ${ }^{1}$. J. Ilgová ${ }^{3} \cdot$ N. Cardillo $^{1,2} \cdot$ M. Ercole $^{1} \cdot$ T. Aronowicz $^{1}$. \\ S. Krivokapich ${ }^{4}$ - M. Kašný ${ }^{3,5}$ • M. Ribicich ${ }^{1}$
}

Received: 24 June 2016 / Accepted: 13 October 2016

(C) Springer-Verlag Berlin Heidelberg 2016

\begin{abstract}
Trichinella patagoniensis, a new species of Trichinella, is widespread in Argentina. The success of parasite transmission depends, among other factors, on the resistance of L1 larvae present in the muscle tissue (ML) of dead hosts undergoing the decomposition process in different environmental conditions. The aim of the present work was to study the infectivity of T. patagoniensis muscle larvae in Cavia porcellus and the capability of the parasite to survive in decomposed muscle tissue of guinea pigs subjected to different environmental conditions. Thirty-two female Ssi:AL guinea pigs were orally inoculated with $2000 \mathrm{ML}$ of $T$. patagoniensis (ISS2311). All the animals were sacrificed 42 days post-infection. Twenty-six animals were eviscerated, and carcasses were placed on the surface of soil inside plastic boxes that were exposed to environmental conditions in the summer 2014-2015 and autumn of 2015 in Buenos Aires, Argentina. Carcasses from six animals were placed into a plastic box inside the refrigerator at a temperature of $4{ }^{\circ} \mathrm{C}$. The muscle tissue samples from the carcasses were examined weekly for the presence of larvae, and
\end{abstract}

F. Fariña

fernandoaf@fvet.uba.ar

1 Facultad de Ciencias Veterinarias, Cátedra de Parasitología y Enfermedades Parasitarias, Universidad de Buenos Aires, Av. Chorroarín 280, C1427CWO CABA, Argentina

2 Consejo Nacional de Investigaciones Científicas y Técnicas (CONICET), CABA, Argentina

3 Department of Botany and Zoology, Faculty of Science, Masaryk University, Kotlářská 2, 61137 Brno, Czech Republic

4 Departamento de Parasitología, INEI, ANLIS, “Dr. Carlos Malbrán”, Buenos Aires, Argentina

5 Department of Parasitology, Faculty of Science, Charles University in Prague, Viničná 7, 12800 Prague, Czech Republic the infectivity of recovered ML was tested in BALB/c mice. Our results showed for the first time the ability of T. patagoniensis to complete its life cycle in guinea pigs, thus serving as a potential natural host. Also, larvae of T. patagoniensis remained infective in muscle tissue for several weeks while undergoing decomposition under different environmental conditions.

Keywords Trichinella patagoniensis $\cdot$ Persistence in decomposing muscle tissue $\cdot$ Infectivity $\cdot$ Guinea pigs $\cdot$ Cavia porcellus

\section{Introduction}

Trichinellosis is a worldwide zoonotic disease caused by parasites from the genus Trichinella.

The first report of human trichinellosis in Buenos Aires, Argentina, was reported in 1898, and it currently is accepted in this country as an endemic disease, transmitted mainly by the consumption of raw or undercooked pork (Ribicich et al. 2005). During 2014, 1120 human cases were notified by the Health Surveillance National System; provinces of Buenos Aires (58.75\%), Córdoba $(17.58 \%)$, Corrientes $(7.05 \%)$, and Santa Fé (5.26\%) reached the highest records (Anonymous 2014).

Until 2008, Trichinella spiralis was the only Trichinella species involved in animal foci and human outbreaks (Fariña et al. 2012). Krivokapich et al. (2008) reported a new genotype, Trichinella T12, and subsequently described it as a new species, Trichinella patagoniensis (Krivokapich et al. 2012). It was determined that $T$. patagoniensis is widespread in Argentina, with the cougar (Puma concolor) serving as a natural reservoir (Krivokapich et al. 2012). 
Recently, it was shown that cats and mice are more susceptible to the infection of T. patagoniensis than rats and pigs (Krivokapich et al. 2012; Ribicich et al. 2013). The transmammary route of infection in $\mathrm{BALB} / \mathrm{c}$ mice does not play an important role in the transmission of T. patagoniensis (Fariña et al. 2016). Moreover, it was demonstrated that, although this parasite can reach the adult stage, it is not able to complete its life cycle in chickens (Gallus gallus domesticus) (Pasqualetti et al. 2014).

Experimental infections of guinea pigs (Cavia porcellus) have been performed, and their susceptibility to various Trichinella species was recorded (Nasinyama et al. 1991; Kapel et al. 1998; Dzik et al. 2002; Leclair et al. 2004; Webster and Kapel 2005). Until now, T. patagoniensis has not been included in such studies, and there is also a lack of information concerning the transmission of T. patagoniensis in nature.

The aim of the present work was to study the infectivity of T. patagoniensis muscle larvae in Cavia porcellus and the capability of the parasite to survive in decomposed muscle tissue of guinea pigs subjected to different environmental conditions.

\section{Materials and methods}

\section{Parasite}

T. patagoniensis isolate (ISS2311) was obtained after the artificial pepsin digestion of muscles of a naturally infected cougar (Puma concolor) from the Province of Rio Negro, Argentina. The parasite has been maintained by serial passages through $\mathrm{BALB} / \mathrm{c}$ mice.

\section{Animals}

Thirty-two female Ssi:AL guinea pigs from the Statens Serum Institut from Denmark weighing $300 \pm 50 \mathrm{~g}$ were purchased from Biol Laboratory, Buenos Aires. The animals were housed in groups of two females in cages with wood shavings, in an environment with a constant temperature of $19-22{ }^{\circ} \mathrm{C}$, a humidity of 55-60\%, and a 12-h day-night cycle. The animals were fed standard guinea pig food and were supplemented with vitamin $C$ in water-as they lack the terminal enzyme for vitamin $\mathrm{C}$ synthesis and must obtain it from dietary sources (McFadden et al. 2005) - all of which were given ad libitum. Before the start of the experiment, the guinea pigs had a 7-day period to acclimatize to their new environment. The thirty-two animals were orally inoculated with $2000 \mathrm{ML}$ of T. patagoniensis.

After 42 days, all the animals were anesthetized with ketamine $50 \mathrm{mg} / \mathrm{kg}$ IM plus xylazine $2 \mathrm{mg} / \mathrm{kg} \mathrm{IM}$ and then sacrificed with an intra-peritoneal injection of $200 \mathrm{mg} / \mathrm{kg}$ sodium pentobarbital.

\section{Experiments}

The study was divided into three independent experiments. As the high temperatures of the summer contributed to the fast putrefaction of the carcasses and in order not to run out of decomposed meat to perform the experiments, the number of guinea pigs employed in experiment 1 was higher than that in experiments 2 and 3.

The experiment 1 (16 animals) was conducted in the summer, from December 19, 2014 to January 9, 2015; the experiments 2 (10 animals) and 3 ( 6 animals) during the autumn and early winter, from May 6, 2015 to June 24, 2015. All the experiments were performed in natural conditions at the Facultad de Ciencias Veterinarias, Universidad de Buenos Aires, Argentina. The data, such as temperature, humidity, and rainfalls, were obtained from the National Weather Service from Argentina (Anonymous 2015a).

\section{Persistence of $T$. patagoniensis ML in decomposing muscle tissue}

The animals from the experiments 1 and 2 were eviscerated and carcasses then placed on the surface of soil inside plastic boxes without having any contact with other carcasses or sides of the box. Boxes were covered with metallic mosquito nets in order to prevent the entrance of arthropods and then were exposed to the environmental conditions of the selected period (see above); the access of non-essential people and animals was prevented. The animals from the experiment 3 were eviscerated, and the carcasses were placed on a plastic box inside the refrigerator, at $4{ }^{\circ} \mathrm{C}$.

At week 0 , several muscle samples taken from three animals, including the posterior limb, the diaphragm, the anterior limb, the intercostals, and the masseter (10 $\mathrm{g}$ in total), were subjected to an artificial digestion procedure (Gamble et al. 2000) directly after euthanasia. Weekly, $10 \mathrm{~g}$ of tissue was analyzed by using the aforementioned method. Trichinella ML were counted employing a stereomicroscope.

In order to assess the infectivity and reproductive capacity index (RCI) of the recovered larvae, three $20 \mathrm{~g}$ female BALB/ c mice were orally inoculated with $300 \mathrm{ML}$ in a volume of $15 \mu$ l. Six weeks post-infection, mice were sacrificed by cervical dislocation and the carcasses processed by the artificial digestion method (Kapel and Gamble 2000).

\section{Statistical analysis}

Following the Shapiro-Wilks test for normality, RCI mean values among the three experiments were assessed for each week of study by an ANOVA parametric test. In the weeks in 
which statistical significance was found, the Tukey test was performed to compare the RCI means among each experiment. The level of statistical significance used was $p<0.05$. Statistix 7 software was used for statistics.

\section{Results}

Guinea pigs became successfully infected with T. patagoniensis. ML were recovered from decaying muscle of animals up to 3 weeks of exposure to summer conditions (experiment 1 ). During the experiment 2, recovery of ML from decomposing guinea pig was done up to 8 weeks of exposure to autumn conditions while in the experiment 3 , it was done up to 11 weeks of exposure to $4{ }^{\circ} \mathrm{C}$.

The RCI values calculated for BALB/c mice infected with ML recovered from guinea pigs are shown in Table 1.

During the summer (experiment 1), the mean maximum temperature (MMT) recorded was $28.9^{\circ} \mathrm{C}$, the temperature range (TR) was from 34.5 to $11.9{ }^{\circ} \mathrm{C}$, the mean minimum temperature $(\mathrm{MmT})$ was $18.2{ }^{\circ} \mathrm{C}$, and the mean average temperature (MAT) was $23.6{ }^{\circ} \mathrm{C}$ with a mean humidity of $63.2 \%$. In the autumn, the MMT was $19.7^{\circ} \mathrm{C}$, the TR was from 27.5 to $1.2{ }^{\circ} \mathrm{C}$, the $\mathrm{MmT}$ was $10.4{ }^{\circ} \mathrm{C}$, and the MAT was $14.4^{\circ} \mathrm{C}$ with a mean humidity of $75.5 \%$. Rainfalls were frequent during the summer of $2014 / 2015$ but not during the autumn of 2015 .
At week 4 in the experiment 1 , at week 9 in the experiment 2 , and at week 12 in the experiment 3 , the absence of muscle tissue due to the decomposition process prevented the recovery of ML, and therefore the inoculation of the mice.

During the third week of study, the significant differences in the RCI mean values between the experiment 1 and the other two experiments ( 2 and 3 ) were recorded. During the fourth, fifth, sixth, seventh, and eighth week, the significant statistical differences in the RCI mean values were found between the experiments 2 and 3 . For the first and second week of the study, no significant differences were found in the RCI mean values between the experiments 1, 2, and 3 (Table 1).

\section{Discussion}

The presented results show for the first time that $T$. patagoniensis is able to complete its life cycle in guinea pigs (Cavia porcellus), and thus, they could act as potential hosts for this parasite. Herbivore infections have been related mainly to a high prevalence of domestic trichinellosis (T. spiralis) and more rarely to sylvatic trichinellosis (T. britovi and T. murrelli), suggesting that unusual hosts acquire the infection when there is a high level of environmental contamination with Trichinella-infected meat scraps (Pozio 2002). A possible way of indirect infection might be by consuming Trichinella-infested meat with plants, water, or soil (Segliņa et al. 2015).
Table 1 Infectivity of muscle larvae (ML) recovered from decomposed guinea pig carcasses as determined by oral inoculation of mice $(\mathrm{RCI})$

\begin{tabular}{|c|c|c|c|c|c|}
\hline \multirow[t]{2}{*}{ Time of exposure } & \multicolumn{3}{|c|}{ Mean of ML recovered from three mice $\mathrm{e}^{\mathrm{d}} / \mathrm{RCI}^{\mathrm{e}}$} & \multirow[t]{2}{*}{$F^{\mathrm{c}}$} & \multirow[t]{2}{*}{$p$ value } \\
\hline & Experiment no. $1^{\mathrm{b}}$ & Experiment no. $2^{\mathrm{b}}$ & Experiment no. $3^{\mathrm{b}}$ & & \\
\hline Week $0^{\mathrm{a}}$ & $10,856 / 36.2$ & $10,333.3 / 34.4$ & & - & - \\
\hline Week 1 & $9385 / 31.3$ & $8360 / 27.9$ & $9526.7 / 31.8$ & 1.42 & 0.3126 \\
\hline Week 2 & $4590 / 15.3$ & $4580 / 15.3$ & $6850 / 22.8$ & 2.39 & 0.1729 \\
\hline Week 3 & 0 & $4683.3 / 15.6$ & $7008.3 / 23.4$ & 21.11 & 0.0019 \\
\hline Week 4 & - & $2716.7 / 9.1$ & $5266.7 / 17.6$ & 23.81 & 0.0082 \\
\hline Week 5 & - & $1900 / 6.3$ & $5016.7 / 16.7$ & 19.42 & 0.0116 \\
\hline Week 6 & - & $1783.3 / 5.9$ & $4100 / 13.7$ & 14.43 & 0.0191 \\
\hline Week 7 & - & $480 / 1.6$ & $3066.7 / 10.2$ & 30.95 & 0.0051 \\
\hline Week 8 & - & 0 & $2900 / 9.7$ & 81.39 & 0.0008 \\
\hline Week 9 & - & - & $2133.3 / 7.1$ & - & - \\
\hline Week 10 & - & - & 1933.3 / 6.4 & - & - \\
\hline Week 11 & - & - & $1900 / 6.3$ & - & - \\
\hline
\end{tabular}

${ }^{\text {a }}$ Previous to the placing of the carcasses into the soil

${ }^{\mathrm{b}}$ Experiment nos. 1 and 2: guinea pig carcasses subjected to summer conditions, the temperature range (TR) was from 34.5 to $11.9^{\circ} \mathrm{C}$ with a mean humidity of $63.2 \%$, and autumn, the TR was from 27.5 to $1.2{ }^{\circ} \mathrm{C}$ with a mean humidity of $75.5 \%$ environmental conditions, respectively. Experiment no. 3: guinea pigs carcasses subjected to $4{ }^{\circ} \mathrm{C}$

${ }^{\mathrm{c}} F$ critical values

d Mean number of larvae recovered from three mice

${ }^{\mathrm{e}} \mathrm{RCI}$ calculated as mean number of larvae recovered from mice/number of larvae inoculated into mice 
T. patagoniensis survived in decomposing muscle tissue until the third week (experiment 1), although at this time, every larva was C-shaped and elongated, and showed no movement. ML remained infective until the second week showing that they can be infective for animals with scavenger habits under summer environmental conditions. High temperatures and rainfalls during the experiment 1 (Anonymous $2015 b$ ) contributed to the acceleration of muscle tissue putrefaction until the fourth week when the carcasses were reduced to bones and skin. In comparison to other Trichinella species, T. patagoniensis would probably be able to survive longer in decaying muscle in summer conditions. Infective larvae of Trichinella papuae were recovered until day 9 from a pig carcass exposed to simulated environmental conditions, TR between 22 and $33{ }^{\circ} \mathrm{C}$ and the relative humidity (RH) $79 \%$ (Owen and Reid 2007). In addition, the infective larvae of T. spiralis larvae were recorded in decayed muscle tissue of rats exposed to natural environmental conditions for 2 weeks (weekly average range $18.5-25.5^{\circ} \mathrm{C}$, average humidity $66 \%$ ) (Oivanen et al. 2002). Interestingly, mouse muscle tissue with T. spiralis ML was infectious only until the end of the first week when subjected to a mean temperature of $23.4{ }^{\circ} \mathrm{C}$ and a mean HR 54.7 \% (Riva et al. 2012).

The ability of $T$. patagoniensis ML to survive inside decaying muscle was higher in autumn (experiment 2 ) than that in summer. Although humidity was higher in autumn than that in summer, low temperatures and scarce rainfalls might be among the causes of a higher larval survival rate.

Survival of Trichinella spp. ML in dead host muscle tissue exposed to low temperatures was proposed as a key factor in its sylvatic transmission among wildlife (Pozio et al. 1992). ML of T. patagoniensis were able to remain infective for 11 weeks in decaying muscle tissue of guinea pigs subjected to a temperature of $4{ }^{\circ} \mathrm{C}$. This result is in concordance with that of other authors (Malakauskas and Kapel 2003; Riva et al. 2012) who showed that low temperatures contribute to the survival of ML of T. spiralis, T. nativa, T. britovi, T. pseudospiralis, and Trichinella T6 in muscle tissue.

From the present research, it can be seen that $T$. patagoniensis ML in carcasses would be more susceptible to the weather conditions that take place in the summer than that in the autumn. Although the time during which the larvae remained infective is short, the successful transmission from infectious carcasses to other hosts is possible (von Köller et al. 2001).

It was demonstrated that $T$. patagoniensis larvae remained infective for 3 months in frozen cat muscles $\left(-5{ }^{\circ} \mathrm{C}\right)$ (Krivokapich et al. 2012). It was verified that in nature, two mechanisms, such as anaerobic processes and temperature, significantly influence the survival rate of Trichinella larvae in tissue of dead animals (Gottstein et al. 2009).

In conclusion, the negative correlation between the high temperature (during a summer) and persistence of ML of T. patagoniensis present in decomposing tissue of guinea pig carcasses was recorded. Consequently, during the colder seasons, the risk of $T$. patagoniensis infection for animals with scavenger habits would be relatively high.

Acknowledgements This study was supported by grants from MINCyT PICT 2013 - 0965 and UBACyT 20020130100336BA. The research of M.K. and J.I. was financially supported by the The Ministry of Education, Youth and Sports of the Czech Republic (7AMB15AR020 and LH12096), Masaryk University, Brno (MUNI/A/1325/2015) and the Charles University in Prague (PRVOUK P41, UNCE 204017 and SVV 260202/2015).

Compliance with ethical standards The present research was performed in compliance with the Guide for the Care and Use of Laboratory Animals of the National Institutes of Health and was approved by the Committee for the Use and Care of Laboratory Animals (CICUAL) of the Facultad de Ciencias Veterinarias, University of Buenos Aires, under permit number 2014/01.

\section{References}

Anonymous (2014) Boletín integrado de vigilancia. Ministerio de Salud de la República Argentina. Presidencia de la Nación. http://www. msal.gov.ar/images/stories/boletines/Boletin\%20Integrado\%20 De\%20Vigilancia\%20N200-SE52.pdf. Accesed 11 June 2016

Anonymous (2015a) Servicio Meteorológico Nacional. http://www.smn. gov.ar/. Accesed 11 June 2016

Anonymous (2015b) Servicios Climáticos. Servicio Meteorológico Nacional. http://www.smn.gov.ar/serviciosclimaticos/clima/archivo/verano.pdf. Accesed 10 June 2016

Dzik JM, Gołos B, Jagielska E, Kapała A, Wałajtys-Rode E (2002) Early response of guinea-pig lungs to Trichinella spiralis infection. Parasite Immunol 24(7):369-379

Fariña F, Scialfa E, Bolpe J, Pasqualetti M, Rosa A, Ribicich M (2012) Study of Trichinella spp. in rodents that live near pig farms in an endemic region of the province of Buenos Aires, Argentina. J Bacteriol Parasitol 3:140

Fariña FA, Pasqualetti MI, Cardillo N, Aronowicz T, Ercole M, Krivokapich SJ, Ribicich M (2016) Evaluación de la transmisión galactógena de Trichinella patagoniensis en ratones BALB/c. Rev Argent Microbiol 48(2):101-104

Gamble HR, Bessonov AS, Cuperlovic K, Gajadhar AA, Van Knapen F, Noeckler K, Schenone H, Zhu X (2000) International commission on trichinellosis: recommendations on methods for the control of Trichinella in domestic and wild animals intended for human consumption. Vet Parasitol 93:393-408

Gottstein B, Pozio E, Nockler K (2009) Epidemiology, diagnosis, treatment, and control of trichinellosis. Clin Microbiol Rev 22:127-145

Kapel CMO, Gamble HR (2000) Infectivity, persistence, and antibody response to domestic and sylvatic Trichinella spp. in experimentally infected pigs. Int J Parasitol 30:215-221

Kapel CMO, Webster P, Lind P, Pozio E, Henriksen SA, Murrell KD, Nansen P (1998) Trichinella spiralis, Trichinella britovi, and Trichinella nativa: infectivity, larval distribution in muscle, and antibody response after experimental infection of pigs. Parasitol Res 84:264-271

Krivokapich SJ, Gonzalez Prous CL, Gatti GM, Confalonieri V, Molina V, Matarasso H, Guarnera E (2008) Molecular evidence for a novel 
encapsulated genotype of Trichinella from Patagonia, Argentina. Vet Parasitol 156:234-240

Krivokapich SJ, Pozio E, Gatti GM, Gonzalez Prous CL, Ribicich M, Marucci G, La Rosa G, Confalonieri V (2012) Trichinella patagoniensis $\mathrm{n}$. sp. (Nematoda), a new encapsulated species infecting carnivorous mammals in South America. Int J Parasitol 42:903-910

Leclair D, Forbes LB, Suppa S, Proulx JF, Gajadhar AA (2004) A preliminary investigation on the infectivity of Trichinella larvae in traditional preparations of walrus meat. Parasitol Res 93:507-509

Malakauskas A, Kapel CMO (2003) Tolerance to low temperatures of domestic and sylvatic Trichinella spp. in rat muscle tissue. J Parasitol 89:744-748

McFadden SL, Woo JM, Michalak N, Dv D (2005) Dietary vitamin C supplementation reduces noise-induced hearing loss in guinea pigs. Hear Res 202(1):200-208

Nasinyama GW, Gordon JC, Bech-Nielsen S, Barriga OO (1991) IgG response in guinea pigs to Trichinella spiralis infection. Vet Parasitol 39(3-4):301-311

Oivanen L, Mikkonen T, Haltia L, Karhula H, Saloniemi H, Sukura A (2002) Persistence of Trichinella spiralis in rat carcasses experimentally mixed in different feed. Acta Vet Scand 43:203-210

Owen IL, Reid SA (2007) Survival of Trichinella papuae muscle larvae in a pig carcass maintained under simulated natural conditions in Papua New Guinea. J Helminthol 81:429-432

Pasqualetti M, Fariña F, Falzoni E, Cardillo N, Aronowicz T, Krivokapich S, Rosa A, Ribicich M (2014) Susceptibility of chickens (Gallus gallus domesticus) to Trichinella patagoniensis. Vet Parasitol 205(1-2):397-400

Pozio E (2002) Factors affecting the flow among domestic, synanthropic and sylvatic cycles of Trichinella. Vet Parasitol 93:241-262

Pozio E, La Rosa G, Rossi P, Murrell KD (1992) Biological characterization of Trichinella isolates from various host species and geographical regions. J Parasitol 78:647-653

Ribicich M, Gamble HR, Rosa A, Bolpe J, Franco A (2005) Trichinellosis in Argentina: an historical review. Vet Parasitol 132:137-142

Ribicich M, Krivokapich S, Pasqualetti M, Gonzalez Prous CL, Gatti GM, Falzoni E, Aronowicz T, Arbusti P, Fariña F, Rosa A (2013) Experimental infection with Trichinella T12 in domestic cats. Vet Parasitol 194:168-170

Riva E, Steffan P, Guzmán M, Fiel C (2012) Persistence of Trichinella spiralis muscle larvae in natural decaying mice. Parasitol Res 111: 249-255

Segliņa Z, Bakasejevs E, Deksne G, Spungíis V, Kurjušina M (2015) New finding of Trichinella britovi in a European beaver (Castor fiber) in Latvia. Parasitol Res 114:3171-3173

von Köller J, Kapel CMO, Enemark HL, Hindsbo O (2001) Infectivity of Trichinella spp. recovered from decaying mouse and fox muscle tissue. Parasite 8:209-212

Webster P, Kapel CMO (2005) Studies on vertical transmission of Trichinella spp. in experimentally infected ferrets (Mustela putorius furo), foxes (Vulpes vulpes), pigs, guinea pigs and mice. Vet Parasitol 130:255-262 